\title{
The Value Dichotomy Curse of Ukraine's Modernization: to Break, or not to Be
}

\author{
Igor Piliaiev
}

Doctor hab. in Political Sciences, Leading Researcher, Institute for Economics and Forecasting of the National Academy of Sciences of Ukraine (Kyiv, Ukraine)

E-mail: igor.piliaiev@i.ua

https://orcid.org/0000-0001-7509-3158

Piliaiev, Igor (2019) The Value Dichotomy Curse of Ukraine's Modernization: to Break, or not to Be. Ukrainian Policymaker, Volume 5, 68-76. https://doi.org/10.29202/up/5/8

The article explores the reasons for failure of modernization of contemporary Ukrainian society hitherto. The conclusion about their deep value nature is grounded. Hence, it is proposed to look for ways of successful modernization based on pivotal cultural and historical traditions that have a consolidating, consensus character for all regions of multicultural Ukraine and for the Ukrainian civil nation as a whole.

Keywords: modernization, values, dichotomy, European integration

Received: October 19, 2019; accepted: November 11, 2019

\section{Introduction}

Ukraine's really successful modernization and European integration presuppose the presence of values, rules and institutions inherent in competitive market economy and structural liberal democracy. Meanwhile, the ruling elite of Ukraine, like of most post-Soviet countries, is characterized by the absence of any stable, uninterrupted for generations spiritual doctrine, traditional values (in fact, in the twentieth century those countries passed twice through a sudden collapse of the old system of established values and norms), anomie (in particular, a weak effectiveness of externally professed legal, religious and moral norms as a means of normative regulation of behaviour), opportunism

(C) Piliaiev, Igor, 2019 
in making strategic decisions, etc. Meanwhile, the political system instability ${ }^{1}$ practically for all the period of independence has not allowed formulating and realizing the national strategy for social and economic development.

Statistical and econometric estimates lately made by the Institute for Economics and Forecasting of the National Academy of Sciences of Ukraine show the formation of a clear trend since 2014 towards the socio-economic divergence of Ukraine and the EU - in fact, perhaps the most important indicator of Ukraine's system modernization failing. It is statistically substantiated that "for the post-Euromaidan period of 2014-2018 such mechanisms of European integration as the implementation of the Association Agreement with the EU, the introduction of a "no-visa" and deep free trade zone, formally pro-European socio-economic reforms in recent years, etc., do not provide the expected macroeconomic, institutional, integration and convergence effect for Ukraine" (Burlay, 2019: 78). That requires urgent developing and implementing the national policy aimed at overcoming the above divergence trend and promoting the opposite trend towards the Ukraine - EU institutional and socioeconomic convergence.

Despite numerous works by Ukrainian and foreign scholars on the problems of modernization and European integration of Ukraine, the former still lack a synergistic approach to understanding and interpreting the basic dichotomies that had and have a decisive influence on the above processes. That, in turn, leads to a false logic of "zero-sum game", separating geopolitical and political-regime factors from historical and cultural values, the absolutization of certain mental paradigms, and so on, that on the eve of the Euromaidan events and the armed conflict in the east of Ukraine was pointed out, for example, by Ukrainian political scientist Sergiy Tolstov (Tolstov, 2013: 42-43).

The foregoing makes appeal to the deep historical, socio-cultural and, ultimately, value causal origins for nearly thirty years of Ukraine's modernization impasse to try to understand why numerous attempts to radically overcome the Ukraine haunting value dichotomy failed. In addition, finally, after determining the key problems and contradictions of the indicated dichotomy, we shall try to outline the ways of the "stitching" and genuine modernization of Ukraine as a state and society.

\section{Main Text}

The dichotomy of values, civilizational and cultural aspirations is inherent in Eurasia both by definition (in fact, its very name implies the duality of the continent's two different wings) and historically, especially since the Mongol invasion. Moreover, such a dichotomy of classical Europe (that is Europe of the historical space of the Carolingian Empire) and classical Asia, as a zone of active civilization influence of the "Celestial Empire" ("Great China"), is a universal property of the whole post-Soviet space at the macro-regional, national, regional, subregional and local levels. We have shown that this dichotomy has a fractal nature, i.e., in practically every society, at each of its structural levels, there is a potential of both the East and the West. The question is in their dynamic proportions (Piliaiev, 2015).

${ }^{1}$ For instance, before the Prime Minister's cadence of Vladimir Groysman (April 2016 - August 2019), the Prime Minister's average term in independent Ukraine was about 1 year (Amelin, 2016), and most political parties (such as President V. Zelensky's Servant of the People, "The Opposition Platform For Life", "Holos [Voice]"), which won the parliamentary elections on July 21, 2019, did not even exist during the previous electoral cycle (2014-2015). 
In our opinion, fruitful for understanding the nature and root causes of both the strategic crisis over Ukraine and the Ukraine's modernization failing would be to use, along with the fractality category, the concepts of limitroph and frontier states.

It should be noted that the term "limitrophic states" was actively used in European geopolitics of the interwar period. A Soviet perestroika, then Russian late philosopher of history and political scientist Vadim Tsymbursky, born in Lviv, modernized this definition by linking it to the concept of the "inter-civilization belt", where there are geopolitically unstable border zones, "territories-straits" between "civilizational platforms" with broken traditions of continuity, the disordered management systems and forms of self-identification of the population. This previously known term was re-activated in the vocabulary of modern political science - now in relation to new states that declared their sovereignty during the collapse of the USSR (Tsymbursky, 1993; Tsymbursky, 1997). In fact, the concept of the "frontier civilization" proposed by Ukrainian political philosopher Sergiy Datsyuk is very close to the above-mentioned "inter-civilization belt" concept (Datsiuk, 2016).

In Ukrainian political science, the term "limitroph" with regard to Ukraine was introduced by a prominent Ukrainian political philosopher Mykola Mikhalchenko, who defines it as a peculiar, frontier situation of Ukraine beneficial both to Western countries and Russia because it allows them to avoid direct military contact at the border (Mikhalchenko, 2000; Mikhalchenko, 2001).

The present Eastern Europe limitrophs (Ukraine, Moldova, with significant reservations Belarus) are characterized by conflicting ethno-political and cultural-civilizational identities. For Ukraine and Moldova, this is manifested in sharp fluctuations in the course of domestic (including cultural- humanitarian) and foreign policy: from somewhat pro-Eurasian, which relies on post-Soviet mentality, to radically pro-European and pro-Western (in fact, far enough from Western standards of rule of law, separation of powers, tolerance, rationalism, etc.).

Meanwhile, Volodymyr Gorbulin, Oleksandr Vlasyuk, and Serhiy Kononenko define Ukraine's historical mission in the system of geopolitical coordinates in the role of "outpost and shield of the Euro-Atlantic world on the Eastern European and Eurasian-Continental territories" (Gorbulin et al., 2015: 21). At the same time, the above authors, in the context of radical restructuring the Eastern European space in connection with the Euromaidan and the Ukrainian-Russian armed conflict, strategize the formation of a new historical and cultural "layer" of the Euro-Atlantic community "within the former Kyievan Rus" which would delimitate the Euro-Atlantic world and continental Eurasia, "protecting the eastern borders of the former world" (Gorbulin et al., 2015: 24). Sergiy Datsyuk (Datsyuk, 2016), while arguing with the aforementioned authors, directly determines that Ukraine belongs to the "civilization of the Frontier". He stresses, "the frontier civilization strategy is fundamentally different from the countries of the united Europe or Russia as a country of north-east Eurasian continental integration". Thus, Datsyuk insists on the urgent need, in the context of overcoming the challenges of Russian aggression and the prolonged socio-economic crisis, for the construction of a "fundamental theory of frontline strategy in Ukraine". However, according to Datsyuk, the Ukrainian ruling elite, because of their total corruption and social irresponsibility, has not yet realized this need (Datsyuk, 2016).

The East-West fractal dichotomy as it were sets the nature of conflicts in the limitrophic, frontier space of post-Soviet Eastern Europe.

The East-West geo-axiological fractal dichotomy, which correlates with the value opposition of "power-freedom", in the Cold War era in Europe in the most pronounced 
institutional form passed along the German-German border. According to Der Tagesspiegel, "The Germans were integrated into military alliances - both in the West and in the East. It was a kind of guarantee that they (the Germans - I. P.) would never again wake up with ambitions to unleash aggressive wars and enslave their neighbors" (Marschall \& Grabitz, 2017). After the collapse of the USSR and the Eastern Bloc (Warsaw Pact) headed by it, the geopolitically and institutionally demarcated border of dominant influence in the East-West dichotomy gradually shifted further to the east, still formalizing itself in the form of a line of contact of the conflicting parties according to the 2014-2015 Minsk Agreements. Meanwhile, the dichotomous "black and white" juxtaposition of "Russia - the West" has been growing rapidly, especially since spring 2014, in both the Ukrainian, the Russian and the Western discourse.

During periods of military and geopolitical confrontation, cultural-value dichotomy is most pronounced and acute. Therefore, in the context of the post-Euromaidan confrontation between Putin's Russia and the neoliberal West, the trend towards polarization of views on the culturalvalue basis has intensified. For example, Alexander Sytin, a Russian historian and political scientist from the liberal camp, directly argues that Russophobia should come to replace anti-Sovietism as an integral system of historical and political views, considering the only way for Russia to reconcile with the West "through "historical unconsciousness", destructing traditional ties of generations...", "the maximum individualization, depatriarchalization and secularization of life and consciousness" of the people (Sytin, 2017). He is echoed by Polish political analysist Alfred Kshitsky, living in Berlin: "Russia is, regardless of the personal composition of the elite that rules it, is the enemy of the civilized Western world, it was in essence also during the time of the Moscow kingdom, the Russian empire and the USSR" (Kshitsky, 2017).

The armed conflict in the Donbas, as testified by its development for 2014-2019, in contrast to the frozen conflicts in the South Caucasus and Transnistria or post-communist wars in the territory of the former Yugoslavia, has not so much ethnic, but ideological and, more deeply, value-civilized character that manifests itself in the absence of cross-cut ethnic divisions in the political loyalty of civilians in the conflict zone, as well as in the largely economically motivated geography of flows of refugees and displaced persons from the Donbas.

Results of the national survey of Ukraine's population conducted in 2016 by the Institute of Sociology at the National Academy of Sciences of Ukraine clearly testified: "European orientations are not determined by ethnic identity and native language" (Reznik \& Reznik, 2017: 137). Similar conclusions were drawn from his own experience by the Deputy Head of the OSCE Special Monitoring Mission in Ukraine (2014-2018), Swiss citizen Alexander Hug. In an interview to Foreign Affairs magazine a week before his resignation, describing the situation in the conflict zone in the Donbas, he pointed out: "I have seen other conflicts where you have an undercurrent group dynamic, ethnic, religious. You do not have this here. You do not need to think about reconciliation from village to village. It's pure political decisions that are required" (Mackinnon, 2018). The empirical study of the ideological motivations of separatists in eastern Ukraine conducted by Ukrainian philosopher and researcher of postSoviet ideologies Mikhail Minakov, Director of the Ukrainian research program at the Kennan Institute (USA), has also confirmed the primarily ideological and value nature of the conflict (Minakov, 2018: 280-281).

Phase spaces of nonlinear systems contain many images of all possible motions, only one of which is realized at a given time and with given internal and external parameters. All other possible states are virtual until the change of conditions leads to their realization. However, 
just these states, being hidden in reality and virtual until a certain time, most often determine the direction and features of the system's development (Afanas'yeva et al., 2013).

For example, in the early 1980s, Kyiv, like Donetsk, was a fairly typical Soviet city where the vast majority of the population lived in the Soviet ideological, mental, cultural, and every day "matrix". In the first stages of Gorbachev's perestroika, Kyiv (until about mid1988) looked like a "preserve" of the Soviet-Communist nomenclature against the backdrop of the dynamic changes in the ideological and cultural climate of Moscow and Leningrad of the time. However, the national-democratic awakening, which encompassed initially the circles of nationally-minded intellectuals and students, and then the broad masses of the Ukrainian capital, catalyzed socio-cultural and axiological factors of consciousness related to the deep values and traditions of Rus-Ukraine, which resided in the Central-European space of Lithuania, Poland, Rzeczpospolita (the Commonwealth), especially the Lithuanian Statute and Magdeburg Law traditions. These values and traditions had been in a dormant latent state for decades, but had rapidly transformed from virtual factors of consciousness into a real powerful factor of socio-political processes and had profoundly influenced the reformatting of the Kyiv masses' mentality. In Donetsk, however, these factors were very weak and did not significantly affect the reformatting of the mentality of the local population, and information policy in the Donbas during the whole period of independence up to the events of spring 2014 did not contribute in any way to the axiological restructuring of the regional mentality but, on the contrary, only reinforced pro-Russian orientations and nostalgia for the Soviet era.

In Minister for Foreign Affairs of Ukraine in 2014-2019 Pavlo Klimkin's view, the main problem for Russia at present is not Ukraine's future membership in the EU or NATO (since many people in Moscow just don't believe that), but the possibility of "a united, democratic and European Ukraine as a country with post-Soviet legacy that is established and sustained as a state with values completely opposite to Russian ones" (Leng, 2015).

The main divide between Western values and the political culture of Russians lies precisely in relation to individual freedom. As a famous Russian political scientist Alexander Tsipko emphasizes in this context: "the problem is not in Putin, but in the Russian political culture and our political system. It was not Putin who created it, it simply corresponds to our tradition: power in Russia has always been unlimited" (Neef, 2016).

On the contrary, the political system of Ukraine is characterized by a high degree of competitiveness with a simultaneous weakness of political institutions (in particular, political parties), and a generally low level of political and legal culture at all levels of the state, politics and society. If in the Russian Federation, the Republic of Belarus, and the post-Soviet states of Central Asia (except Kyrgyzstan) a representative of authority invariably wins the presidential election $^{2}$, in Ukraine after 1991 four times (in 1994, 2004, 2010 and 2019) a representative of opposition won the presidency (in May 2014 Petro Poroshenko won the presidential election after the victory of Euromaidan which took place at the end of February 2014). However, the very competitiveness of electoral democracy in Ukraine is associated not so much with the struggle of political ideologies, but primarily with the struggle of various clan-oligarchic groups for power, which in such circumstances leads to a whole series of negative consequences for the stability of state and political institutions, the consistency of domestic and foreign policy, economic modernization and international competitiveness of the national economy.

${ }^{2}$ The only exception is the victory of Alexander Lukashenko in the first presidential elections after the declaration of independence of Belarus held in the summer of 1994. 
The Russian annexation of Crimea, the armed conflict in the Donbas and, accordingly, the systemic crisis of Ukrainian-Russian relations have only actualized the problem of civic value consensus within Ukraine. Recently, this problem has been clearly emphasized by President of Ukraine Volodymyr Zelensky: "Ukrainian society needs to agree on each other, and this is very important, because today there are completely different visions of the issue of the return of the Donbas and Crimea inside Ukraine" (Zelensky, 2019).

Ukraine is capable of overcoming the periphery, limitrophic, "gray zone of Europe" syndrome on the path of a thorough reformatting of the ideology of national-state construction, in particular recognition of the historical and cultural heritage, European values and traditions of the Kyivan, Galicia-Volyn and Lithuanian Rus, in particular the Rus region of the Kingdom of Poland and Rzeczpospolita, along with the Ukrainian Hetmanate of the XVII-XVIII centuries, the Ukrainian People's Republic (the UPR) and Pavlo Skoropadsy's Ukrainian State (Hetmanate) of 1918 are the historical and cultural pivot around which the formation of the Ukrainian political nation might successfully take place.

All-Ukrainian dialogue and consensus also involve the involvement of such well-forgotten, but inspiring, unions and civic consensus on the facts of national history, such as the conclusion in August 1920 of a military-political agreement between the UNR under the leadership of the Supreme Commander of the Ukrainian Army, President of the Ukrainian People's Republic Symon Petliura and General Peter Wrangel's Crimean government, with the participation of Chief of State of the Second Polish Republic Józef Piłsudski and under the aegis of the Entente, on the recognition of the powers of the future democratically elected All-Ukrainian Constituent Assembly and the operational inclusion (realized in September-November 1920) of General Boris Permikin's $3^{\text {rd }}$ Russian "White" Army, based in Poland, to the operational grouping of the UPR's Army for joint offensive against the Bolsheviks in Right-Bank Ukraine (Salsky, 1933: 317).

The systemic crisis that has lasted in Ukraine almost since Gorbachev's perestroika, deeply affecting all spheres of life of the state and society ${ }^{3}$, makes us look more critically at the problem of the "aggregating" or "voice-centered" model of democracy, based primarily on formal institutional and procedural mechanisms of popular expression of will. Not to mention the very serious problem of manipulating the will and the electorate's votes, effective control of voting and counting of votes, the issue of the place and role of public discussions, taking into account the views of ordinary voters and minorities, and developing pluralistic dialogue, compromise and consensus formulas (platforms) of public policy (Kymlicka, 2002: 287-293)

The drama-existential challenges that Ukraine faced since 2014 exposed an extremely simplified, imitative (sometimes reminiscent of a cargo cult) understanding of democracy as a voice-centered system of formal procedures, as a result of which - it doesn't matter by what means (through manipulation, coercion, indoctrination, propaganda, deceit, etc.) the necessary numerical superiority is ensured both in elections of state authorities and local self-government, and when legislative bodies adopt laws and other important, sometimes fateful, decisions. Meanwhile, prominent Western theorists of democracy at the turn of the $20^{\text {th }}$ $21^{\text {st }}$ centuries came to the realization of the need to transform voice-centered democracy into the dialogue-centric one.

As Jürgen Habermas emphasized, "institutions guaranteed by constitutional law only have value to the extent that the population makes them value" (Habermas, 1995: 226). A prominent

${ }^{3}$ In 2016, Ukraine's GDP (PPP), according to the IMF, amounted to $63.4 \%$ of the 1990 level (see: International Monetary Fund, 2017). 
Canadian philosopher, Will Kymlicka, considers as the primary condition for the health and stability of democracy that how citizens "consider potentially competing forms of national, regional, ethnic or religious identity", "their ability to be tolerant and work with those who are different from them" (Kymlicka, 2010: 362).

As Ukrainian philosopher Petro Kralyuk from the Ostroh Academy stresses, over the years of independence, despite pro-European declarations and decorations, the Ukrainian authorities essentially did not have and do not have a program to consolidate the population of their state, "they don't have an understanding of what role in this consolidation should have been played by the Ukrainian national factor, and what role national minorities would have to play" (Kralyuk, 2016) And, as Sergey Datsyuk points out, because of the "poor quality of the ruling class", which was evident after the victory of Euromaidan, "the current identity gap in Ukraine leads to a fundamental impossibility to take a strategic position, since every piece of identity is seeking not an internal unity but external subordination" (Datsyuk, 2016).

Voice-centric democracy is clearly not enough in determining the legal status of languages, religions, or cultural rights of persons belonging to minorities. Here, a consensus is needed between the country's main ethnic, ethno-religious and ethno-cultural communities, which can be reached, as, for example, a well-known Ukrainian political scientist Valentin Yakushik suggests, through "development and implementation of democratic mechanisms of public (nation-wide, regional and local) discussions ("public hearings") on the key issues of cultural, socio-economic and political development" (Yakushik, 2018: 83).

\section{Conclusions}

By its basic social parameters, Ukraine is developing as a pluralistic, European-oriented society; the vast majority of its population identifies its origin from the Kyivan, Galicia-Volyn and Lithuanian Rus - European states with strong traditions of self-government, respect for the rights and dignity of the individual, private property, multicultural and multi-faith living environment. The Hordean tradition of government has never been organic for Ukraine. In this regard, the Rus-Ukraine of Zaporizhzhya Sich, the Hetmanate, the Kyiv-Mohyla Academy, the Cyril-Methodius Brotherhood has traditionally acted as a libertarian alternative to the EurasianHorde, authoritarian-despotic form of state multinational unification around Muscovy. In the post-Soviet era, these fundamental differences became apparent again.

In our opinion, the fractal dichotomy of social, political and moral values as well as of geopolitical orientations in Ukraine - Russia relations is likely to increase. The task of the authorities and civil society in Ukraine is to prevent further exacerbation of this dichotomy in Ukraine, to unite society and the Ukrainian political nation around European values.

Meanwhile, history convincingly manifests that a nationwide civic consensus in Ukraine is possible, and just that is capable of ensuring the true modernization of Ukraine as a state, society, national economy as well as the realization of the European Choice and integration into the family of civilized countries and peoples. The platform of national and civic accord envisages the recognition of the European Rus-Ukraine tradition being common to all regions of Ukraine, inherent in its historical and cultural values, and finally, a powerful layer of common axiologically Europe-oriented history. Indicators of value identity should be constantly monitored by authorities, scientists and the public.

Taking into account the aforementioned historical and value paradigm in the Ukrainian authorities and diplomacy's practical actions would contribute to both the settlement of the 
armed conflict and the resumption of peaceful life in the Donbas, as well as to the prevention of conflict threats in other regions of Ukraine. It is the consolidation of the Ukrainian civic nation around the European traditions and values of the Kyivan, Galicia-Volyn, Lithuanian Rus, the Commonwealth and the Hetmanate that, in our opinion, might unite, on the basis of passionate national idea, all regions and segments of the population, major political forces, representatives of civil society, and believers of all traditional denominations of Ukraine.

We consider the true implementation of the European Choice of Ukraine on a path that combines Freedom and, accordingly, European liberal values with the pivotal cultural tradition of European Rus-Ukraine, which permeates, as an axis, the whole array of our national history. Only in this way, a sustainable democratic development and socio-economic recovery of Ukraine can be ensured.

\section{[D] References}

Afanas'yeva, V. V., Kochelayevskaya, K. V., and Lazerson, A. G. (2013). Space: the newest ontology. Saratov: "Nauka". (In Russian).

Amelin, Anatoliy. (2016). 25 Years of Independence of Ukraine: Economic Results. Kyiv: Ukrainian Institute for the Future. URL: http://hvylya.net/analytics/economics/anatoliyamelin-ekonomicheskie-itogi-25-let-nezavisimosti-ukrainyi.html (In Ukrainian).

Burlay, T. V. (2019). Factors of the socio-economic divergence between Ukraine and the European Union. Ukrayins'kyy sotsium, No 2 (69), 61-83. (In Ukrainian).

Datsyuk, Serhiy. (2016). Who needs a strategy in Ukraine? Khvylya. URL: http://hvylya.net/ analytics/politics/kontrstrategiya-dlya-gibresiyi.html (In Ukrainian).

Gorbulin, Volodymyr, Oleksandr Vlasyuk, and Serhiy Kononenko (2015). Ukraine and Russia: The Tenth Wave or the Wall of China. Kyiv: National Institute for Strategic Studies. (In Ukrainian).

Habermas, Jürgen. (1995). Democracy, reason, morality. Lectures and interviews. Moscow: JSC "KAMI"; Publishing Center "Academia". (In Russian).

International Monetary Fund. (2017). Report for Selected Countries and Subjects / World Economic Outlook Database. URL: http://www.imf.org

Kralyuk, Petro (2016). Ukrainian history - what should it be? ZN,UA, June 4, 2016. URL: http://gazeta.zn.ua/HISTORY/ukrainskaya-istoriya-kakoy-ey-byt-_.html (In Russian).

Kshitsky, Alfred. (2017). What should the world community do with Russia? The New "Dulles Plan" for the 21st Century. May 10, 2017. URL: http://hvylya.net/analytics/geopolitics/ chto-mirovomu-soobshhestvu-delat-s-rossiey-novyiy-plan-dallesa-dlya-xxi-veka.html (In Russian).

Kymlicka, Will. (2002). Contemporary Political Philosophy: An Introduction. Oxford University Press.

Kymlicka, Will. (2010). Contemporary Political Philosophy: Introduction. Translated from English by S. Moiseev. Moscow: Publishing House of the State University - Higher School of Economics. (In Russian).

Leng, Rachel. (2015). Fair Elections in Eastern Ukraine Necessary for Future Progress, Says Ukrainian FM. Seoul: The Asan Institute for Policy Studies. September 18, 2015. URL: $\mathrm{http} / /$ en.asaninst.org/contents/real-elections-in-ukraine-necessary-for-future-progresssays-ukrainian-fm/ 
Mackinnon, A. (2018). Counting the Dead in Europe's Forgotten War. Interview with Alexander Hug, the Deputy Head of the OSCE Special Monitoring Mission to Ukraine. Foreign Affairs. October 25, 2018. URL: https://foreignpolicy.com/2018/10/25/counting-thedead-in-europes-forgotten-war-ukraine-conflict-donbass-osce/

Marschall, Ch. Von, and Grabitz, M. (2017). Steht die Nato vor dem Aus? Der Tagesspiegel. February 14, 2017. URL: http://www.tagesspiegel.de/politik/westlichesverteidigungsbuendnis-steht-die-nato-vor-dem-aus/19392156.html

Mikhalchenko, Mykola. (2000). Limitroph of Europe: coincidence or fate of Ukraine? Lyudyna i polityka. No. 3: 34-39. (In Ukrainian).

Mikhalchenko, Nikolay. (2001). Ukrainian society: transformation, modernization or Europe's limitroph? Kyiv: Institute of Sociology of the NASU. (In Russian).

Minakov, Mikhail (2018). Development and Dystopia.Studies in post-Soviet Ukraine and Eastern Europe. Stuttgart: ibidem-Verlag.

Neef, Christian. (2016) "Bereit, alles niederzubrennen". Interview mit Alexander Zipko. Der Spiegel. 4 Juni 2016, No 23. URL: https://www.pocketstory.com/der-spiegel/bereitalles-niederzubrennen

Pakhlovska, Oksana. (2008). Who will protect Abel? Humanitarian policy and the mission of intellectuals. Den'. February 2, 2008, P. 5.

Piliaiev, Igor. (2015). Fractal Localization of the East - West Global Paradigm: an Attempt of Synergetic Analysis of the Armed Conflict in Donbas. Naukovyi visnyk Dyplomatychnoiy akademiiy Ukraiyny [Scientific Bulletin of the Diplomatic Academy of Ukraine]. Vol. 22 (Part II): 112-120. (In Ukrainian).

Reznik, Oleksandr and Volodymyr Reznik. (2017). Ukraine's European Choice as a Social Condition of Democratic Transition. Ideology and Politics. Issue 2 (8): 117-145.

Salsky, Volodymyr (ed.) (1933). The Ukrainian-Moscow War of 1920 in documents. - Part 1: The UPR Army Staff Operational Documents. Warsaw: [without indication of the publisher]. (In Ukrainian).

Sytin, Alexander. (2017). How the world should respond to the terrorist and destructive activities of Russia. February 27, 2017. URL: https://lb.ua/world/2017/02/27/359802 miru_reagirovat.html (In Russian).

Tolstov, Sergiy. (2013). Ukraine between the West and the East: Political, Economic and Social-Humanitarian Aspects. Variations of Modernity and Modernization: Ukrainian society in the Context of Global Processes: Proceedings of the International Scientific and Practical Conference. Compiled by P. V. Kutuyev. Kyiv: Talkom: 41-43. (In Ukrainian).

Tsymbursky, Vadim. (1993). Island Russia (Prospects for Russian Geopolitics). POLIS (Political Studies). No. 5: 6-23. (In Russian).

Tsymbursky, Vadim. (1997). Peoples between civilizations. Pro et Contra. No. 2: $154-184$. (In Russian).

Yakushik, Valentin (2018). Varieties of a Law-Governed State. Ukrainian Policymaker, Volume 3: 72-84. https://doi.org/10.29202/up/3/10

Zelensky believes that the Ukrainian society needs to develop a consensus on the reintegration of the Donbas and Crimea (2019). Interfax-Ukrayina. [Interfax-Ukraine]. 30.10.2019. URL: https://ua.interfax.com.ua/news/political/621690.html 